\title{
BUCKLING CAPACITY CURVES FOR STEEL SPHERICAL SHELLS LOADED BY THE EXTERNAL PRESSURE
}

\author{
Paweł BŁAŻEJEWSKI ${ }^{1}$, Jakub MARCINOWSKI ${ }^{1}$ \\ University of Zielona Góra, Institute of Building Engineering, Poland
}

\begin{abstract}
Assessment of buckling resistance of pressurised spherical cap is not an easy task. There exist two different approaches which allow to achieve this goal. The first approach involves performing advanced numerical analyses in which material and geometrical nonlinearities would be taken into account as well as considering the worst imperfections of the defined amplitude. This kind of analysis is customarily called GMNIA and is carried out by means of the computer software based on FEM. The other, comparatively easier approach, relies on the utilisation of earlier prepared procedures which enable determination of the critical resistance $p_{R c r}$, the plastic resistance $p_{R p l}$ and buckling parameters $\alpha, \beta, \eta, \lambda_{0}$ needed to the definition of the standard buckling resistance curve. The determination of the buckling capacity curve for the particular class of spherical caps is the principal goal of this work. The method of determination of the critical pressure and the plastic resistance were described by the authors in [1] whereas the worst imperfection mode for the considered class of spherical shells was found in [2]. The determination of buckling parameters defining the buckling capacity curve for the whole class of shells is more complicated task. For this reason the authors focused their attention on spherical steel caps with the radius to thickness ratio of $R / t=500$, the semi angle $\varphi=30^{\circ}$ and the boundary condition BC2 (the clamped supporting edge). Taking into account all imperfection forms considered in [2] and different amplitudes expressed by the multiple of the shell thickness, sets of buckling parameters defining the capacity curve were determined. These parameters were determined by the methods proposed by Rotter in [3] and [4] where the method of determination of the exponent $\eta$ by means of additional parameter $k$ was presented. As a result of the performed analyses the standard capacity curves for all considered imperfection modes and amplitudes $0.5 t, 1.0 t, 1.5 t$
\end{abstract}

\footnotetext{
${ }^{1}$ Corresponding author: University of Zielona Gora, Institute of Building Engineering, Szafrana st 1, 65-516 Zielona Gora, Poland, e-mail: p.blazejewski@ib.uz.zgora.pl, j.marcinowski@ib.uz.zgora.pl, tel. +48683282527
} 
were obtained. Obtained capacity curves were compared with the recommendations for different fabrication quality classes formulated in [5].

Keywords: steel spherical shells, buckling resistance, capacity curve, numerical approach, FEM.

\section{INTRODUCTION}

To design steel slender shell structures designers have to fulfill the whole set of so called limit states specified in EN1993-1-6. For the shell in which compressive stresses dominate the buckling limit state (denoted as LS3 in EN1993-1-6) is usually the most decisive. The approach presented in the clause 8.5 of the EN1993-1-6 rely on the determination of the buckling reduction factor $\chi$ which enables the assessment of the buckling resistance on the basis of plastic resistance. $\chi$ is the function of relative slenderness $\lambda$ and this relationship is called the buckling capacity curve. This approach is the very strong and easy tool in designer's hands. There is a problem yet: how to determine four independent parameters defining the buckling reduction factor $\chi$ ? This parameters are: the elastic imperfection reduction factor $\alpha$, the plastic range factor $\beta$, the interaction exponent $\eta$ and the squash limit relative slenderness $\lambda_{0}$. Values of these parameters can be found in the Annex D of the EN1993-1-6 for selected classes of shells. There is no proposal for the spherical shells in the Annex D. An alternative approach has been proposed in [6].

In the present work the derivation of the above mentioned buckling parameters for the segment of spherical shell loaded by the external pressure is presented. Final results in a form of capacity curves were compared with counterparts from [6] for the same amplitudes of imperfections.

To determine the buckling parameters one should perform the sequence of numerical analyses, starting from LBA analyses from which the critical resistance is obtained, then MNA analyses from which the plastic resistance is obtained and finally GMNIA analyses from which the buckling resistance of the shell is obtained. All mentioned analyses in this work were performed by means of the COSMOS/M system [7] based on FEM. Having at disposal the whole set of results of the analyses above for the given class of shells one can proceed to the determination of buckling parameters $\alpha, \beta, \eta, \lambda_{0}$. These coefficients of buckling capacity curve depend on the considered imperfection mode and the adopted imperfection amplitude. The procedure leading to the determination of these parameters was presented on the example of the spherical cap of the radius to thickness ratio $R / t=500$, the semi angle $\varphi=30^{\circ}$ and the clamped supporting 
edge. This shell is presented in Fig. 1 together with the material parameters used in materially nonlinear analyses.

The imperfection mode taken into account in the detailed analyses of the example had the shape of the first buckling mode of the ideal shell and was denoted as the no. 6. In all considered examples the imperfection amplitudes were equal to $0.5 t, 1.0 t$ and $1.5 t$.

The other sets of buckling parameters, for remaining six imperfection modes (seven imperfection modes were considered) and imperfection amplitudes, which equal to $0.5 t, 1.0 t, 1.5 t$ respectively, were determined in the analogous way. Final results were compared with the existing design recommendations [5].

\section{THE STANDARD CAPACITY CURVE}

Rotter [4] has proposed the elastic-plastic buckling interaction rule which, as the standard capacity curve, was later introduced in EN 1993-1-6 as a method of the buckling resistance assessment of steel shells. It takes into account elastic, elastic-plastic and purely plastic buckling states of shells with the worst modes of imperfections. The capacity curve defines the buckling strength reduction factor $\chi$ as the function of the relative slenderness

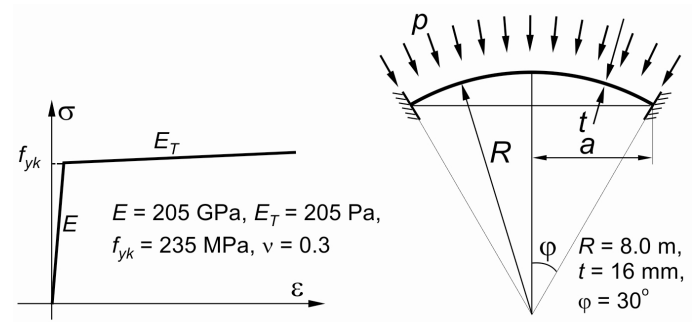

Fig. 1. The materialmodel and the steel spherical shell considered in the work

$$
\lambda=\sqrt{\frac{p_{R p l}}{p_{R c r}}}
$$

where $p_{R c r}$ is the critical pressure obtained for the analysed geometrically perfect shell as a result of LBA (linear buckling analysis) analysis in which only linear material model was taken into account and $p_{R p l}$ is the plastic resistance obtained as a result of MNA (materially nonlinear analysis) analysis for the material model shown in Fig. 1. Both quantities $p_{R c r}$ and $p_{R p l}$ can be treated as reference values in the procedure leading to the buckling resistance assessment.

The buckling strength reduction factor $\chi$ defines the characteristic value of the buckling resistance by means of the plastic resistance. In the case of spherical 
caps loaded by the external pressure $p$ this dependence can be expressed as follows:

$$
p_{R k}=\chi p_{R p l}
$$

where $p_{R k}$ is the characteristic value of the buckling resistance.

To obtain the design value of this quantity one should use the following formula

$$
p_{R d}=\frac{p_{R k}}{\gamma_{M 1}}
$$

in which $\gamma_{M 1}$ is the partial factor for resistance to buckling defined for steel structures in EN1993-1-6 and adopting the value not smaller than 1.1.

The buckling strength reduction factor $\chi$ is defined as follows:

$$
\begin{array}{lll}
\chi=1 & \text { when } & \lambda \leq \lambda_{0} \\
\chi=1-\beta\left(\frac{\lambda-\lambda_{0}}{\lambda_{p}-\lambda_{0}}\right)^{\eta} & \text { when } & \lambda_{0}<\lambda<\lambda_{p} \\
\chi=\frac{\alpha}{\lambda^{2}} & \text { when } & \lambda \geq \lambda_{p}
\end{array}
$$

where: $\lambda_{0}$ is the squash limit relative slenderness, $\lambda_{p}$ is the plastic limit relative slenderness, $\beta$ denotes the plastic range factor and $\eta$ - the interaction exponent.

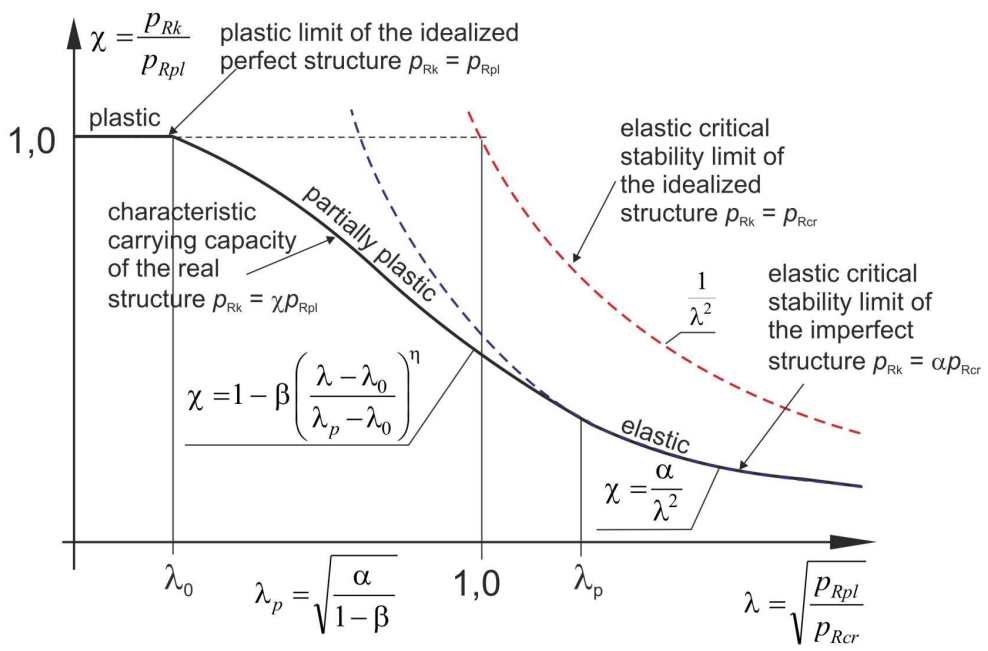

Fig. 2. Standard capacity curve 
The first interval of the relative slenderness $\lambda \leq \lambda_{0}$ means that only purely plastic deformations can occur during complete destruction of the shell. Within the intermediate interval $\lambda_{0} \leq \lambda \leq \lambda_{p}$ the elastic-plastic collapse mechanism can take place. For $\lambda \geq \lambda_{p}$ the collapse mechanism (the buckling) is purely elastic.

The shape of the standard capacity curve is defined by buckling parameters $\alpha$, $\beta, \eta, \lambda_{0}, \lambda_{p}$ and is presented in Fig. 2. Only four buckling parameters are independent. The fifth one $\lambda_{p}$ is defined by the formula:

$$
\lambda_{p}=\sqrt{\frac{\alpha}{1-\beta}}
$$

and this relationship follows from the continuity condition at the transition point from the second to the third interval of the capacity curve.

Knowledge of the capacity curve for the particular case of the shell of definite boundary conditions and the load case allows a designer to assess the buckling capacity. In most cases of shells it is the most decisive parameter as far as design criteria are concerned.

\section{THE MODIFIED CAPACITY CURVE}

The determination of buckling parameters $\alpha, \beta, \eta, \lambda_{0}, \lambda_{p}$ defining the standard capacity curves is not an easy task. Rotter [5] proposed the effective procedure leading to determination of these parameters. To this end so called modified capacity curve should be generated. On the abscissa of this plot the GMNIA/LBA ratio is depicted while on the ordinate the GMNIA/MNA ratio is reproduced. The only variable in these analyses is the value of the yield stress which helps to control the relative slenderness of individual cases. This approach was chosen to the precise determination of all buckling parameters of the definite spherical cap.

The general shape of the modified capacity curve is shown in Fig. 3. The full explanation of this shape is given in [3] and [5].

The curve like this was created for the spherical cap of geometry and other data specified in Fig. 1. The imperfection mode taken into account in the example, which was analysed in details, had the shape of the first buckling mode of the ideal shell and was denoted as no. 6 . The modified capacity curve obtained for the imperfection amplitude equal to $0.5 t$ is shown in Fig. 4. Having this plot the parameter $\alpha=0.313$ and the value of $1-\beta=0.185$ were determined. The first one is defined by the vertical segment of the graph and the other one is 
determined by the level of the fold of this vertical part of the plot. It is worth mentioning that these both parameters strongly affect the final buckling capacity of the shell.

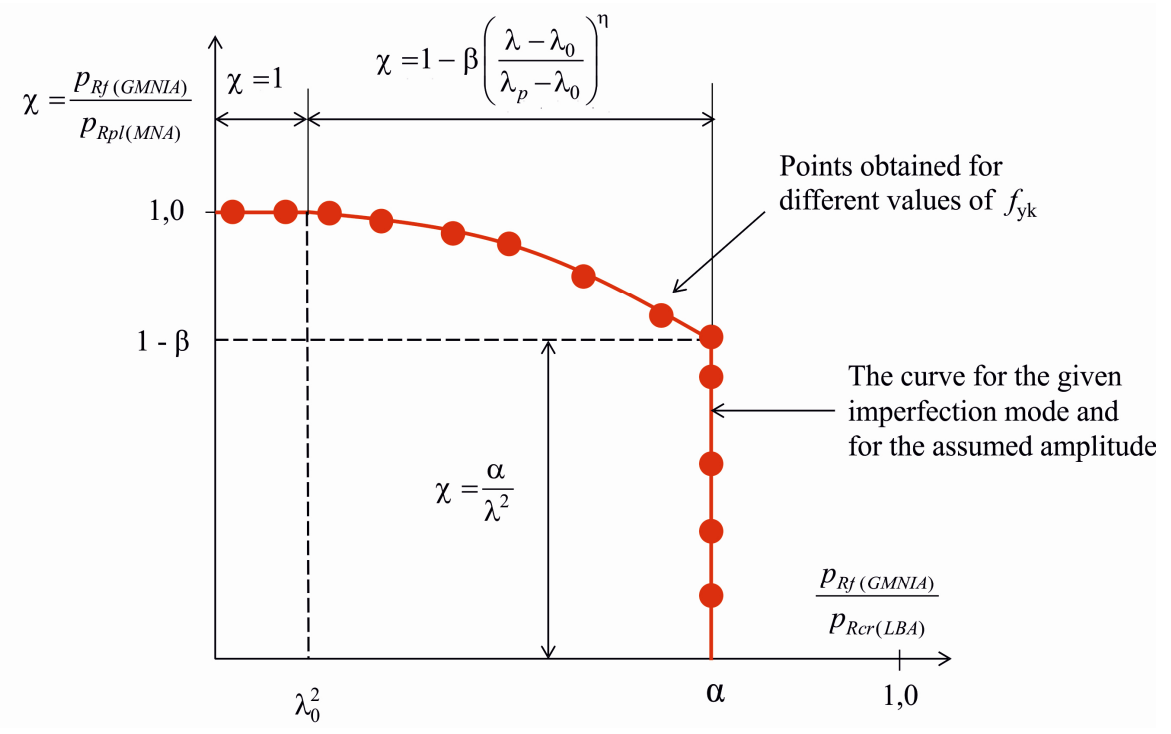

Fig. 3. The modified capacity curve

In the presented case and also in the other considered cases the horizontal segment of modified capacity curve which defines the value $\lambda_{0}{ }^{2}$ was not registered. For this reason in all analysed cases it was assumed that this parameter adopts the value $\lambda_{0}=0$.

To determine the interaction exponent $\eta$ the direct formula proposed by Rotter [5] was adopted. This formula has the following form:

$$
\eta=\frac{\ln (1-k)-\ln \beta}{\ln \left(\sqrt{\alpha}-\lambda_{0}\right)-\ln \left(\sqrt{\frac{\alpha}{1-\beta}}-\lambda_{0}\right)}
$$

In this formula the value of $k$ is required. The value of $k$ is determined as the intersection point of the modified capacity curve with the straight line connecting points $(0,0)$ and $(\alpha, 1)$ and shown by the dashed line in Fig. 4.

In this manner all parameters describing the standard capacity curves $\alpha, \beta, \eta, \lambda_{0}$, $\lambda_{p}$ were determined. Having determined the parameters the standard capacity curves can be plotted for all considered modes of imperfections and for three different amplitudes of imperfection which were taken into account. 


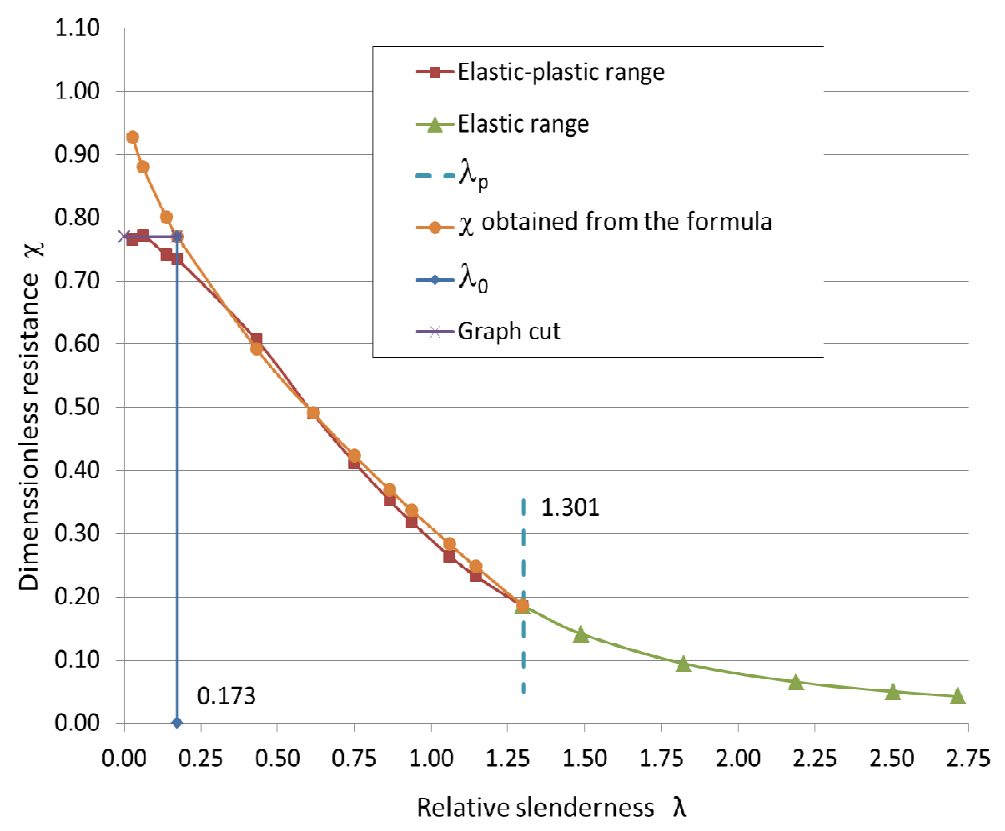

Fig. 5. The standard capacity curve for imperfection mode no. 6 and amplitude $0.5 \mathrm{t}=8.0 \mathrm{~mm}$

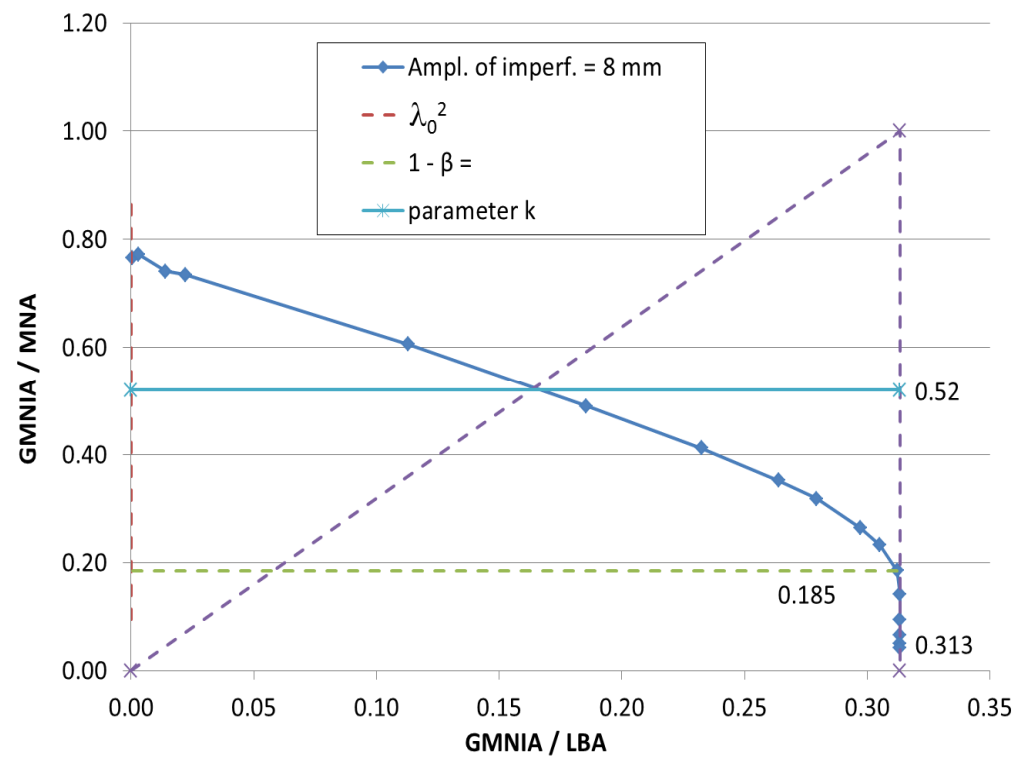

Fig. 4. Modified capacity curve for imperfection mode no. 6 and amplitude $0.5 t=8.0 \mathrm{~mm}$ 


\section{THE STANDARD BUCKLING CAPACITY CURVE}

The knowledge of all parameters describing the standard buckling capacity curve makes it possible to determine the curve without any difficulty. The buckling capacity curve for the particular case considered in clause 3 is presented in Fig. 5.

In this graph it is clearly visible the point of transition from the elastic-plastic range into the purely elastic range. It occurs for the relative slenderness value $\lambda_{\mathrm{p}}$ $=1.301$. Within elastic-plastic range two curves were compared. The first one (maroon squares) was obtained directly from the numerical analyses (the ratio GMNIA/MNA for different $\lambda$ ) and the other one (orange circles) was depicted by means of the standard formulae describing this range of the capacity curve by means of the determined buckling parameters.

It is visible that the maroon curve does not reache the 1.0 level on the ordinate axis, thus the typical plastic plateau was not reached. So the dimensionless buckling resistance adopts the value of 0.78 not the value of 1.0 which follows from the standard formula. Hence, keeping in mind the best fit of the standard plot and obtained numerical results, the necessity of the obtained graph "trimming" has arisen. In this manner the horizontal segment of the buckling capacity curve was created till the abscissa value of 0.173 . Within the remaining range of relative slendernesses $\lambda$ the correspondence of both approaches was achieved on the level of 0.997 . In this figure the capacity curve proposed in [6] was presented as well.

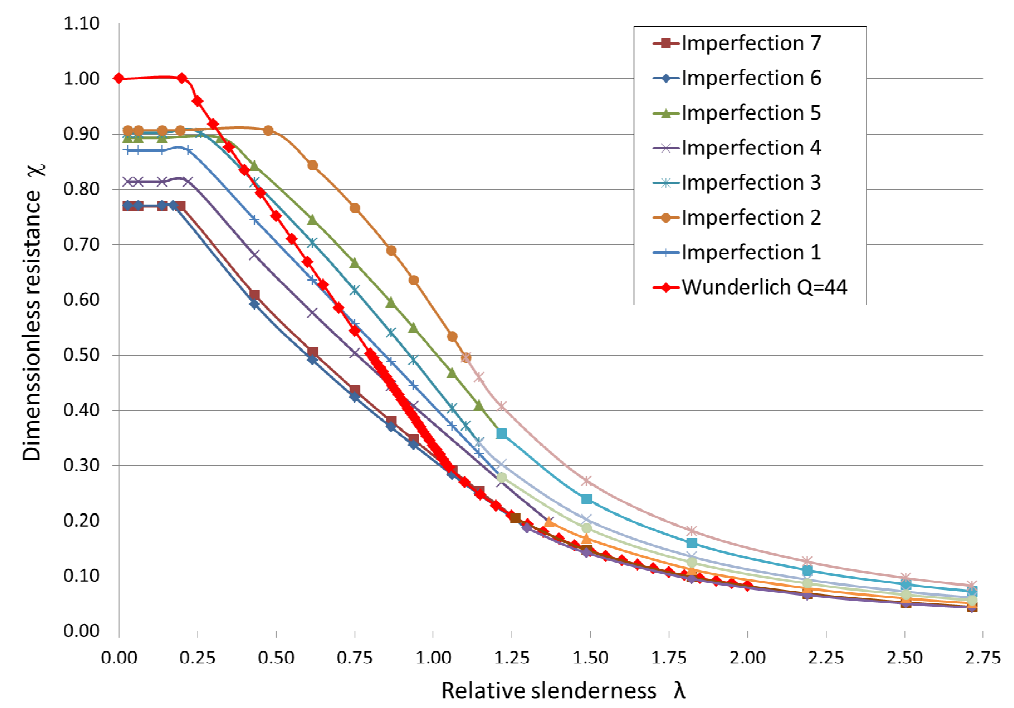

Fig. 6. Standard capacity curves for different imperfection modes of amplitude $0.5 t$ 
In Fig. 6 seven standard capacity curves are presented for imperfection modes analysed in [2] and for the amplitude 0.5t. Additionally in the same figure the capacity curve determined according to EDR 5th [5] for the amplitude $8.1 \mathrm{~mm}$ $(0.5 \mathrm{t}=8 \mathrm{~mm})(\mathrm{Q}=44)$ was presented. It is distinctly seen that none of the analysed shells, with imperfection amplitudes of $0.5 t$, reaches the level of full plastic resistance (the level 1.0). The lowest value of the plastic resistance was equal to 0.78 and was obtained for two different modes of imperfections, namely imperfections no. 6 and no. 7.

Besides, these modes of imperfections (the first and the second buckling modes) exhibit the lower by far level of capacity than the value suggested by the existing recommendations. It refers to the nearly whole elastic-plastic range. It is an evidence that within this range the buckling capacity determined by the procedure proposed in EDR 5th [5] leads to significant overestimation of this important measure of the shell resistance.

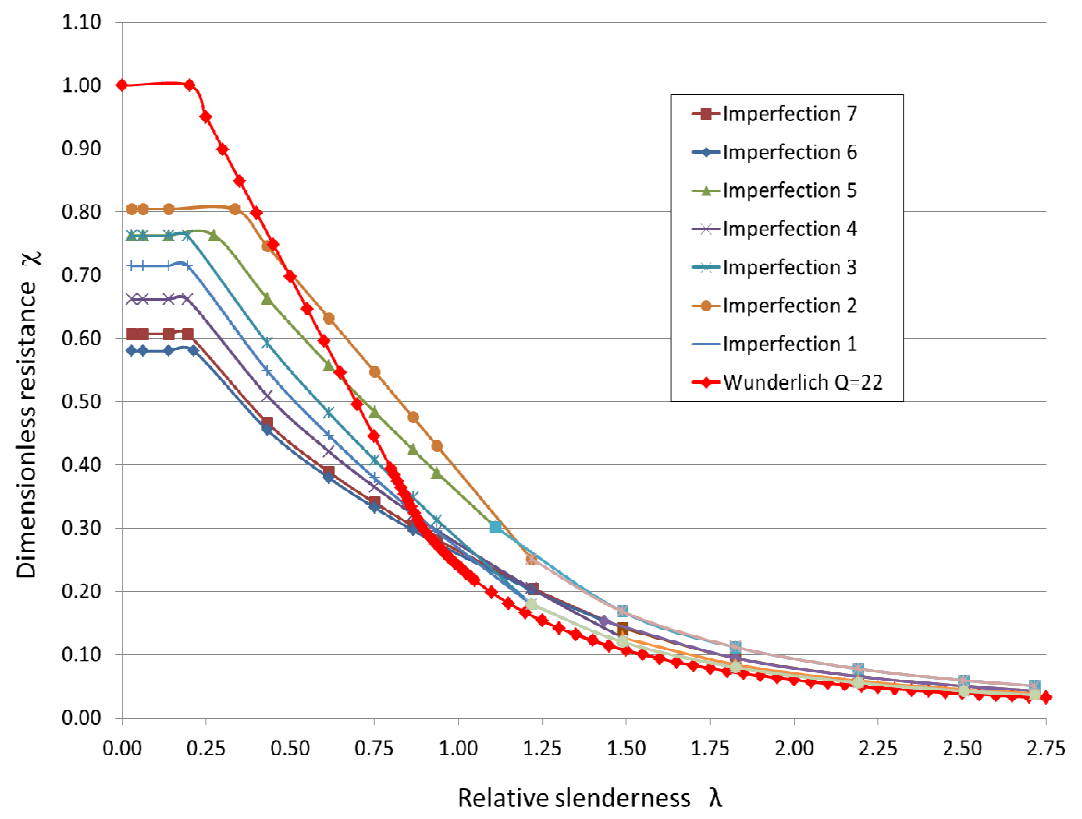

Fig. 7. Standard capacity curves for different imperfection modes of amplitude $1.0 t$

In Fig. 7 and in Fig. 8 analogous standard buckling capacity curves are presented for the same imperfection modes but for larger imperfection amplitudes and namely $1.0 t$ and $1.5 t$ respectively. The obtained capacity curves were again compared with their counterparts proposed in [5]. These families of the capacity curves were obtained in exactly the same way as the capacity curve shown in Fig. 5. 
Figure 9 presents envelopes of capacity curves obtained from the families presented in Figs. 6,7 and 8. These envelopes indicate the actual level of the buckling resistance of the considered spherical shells.

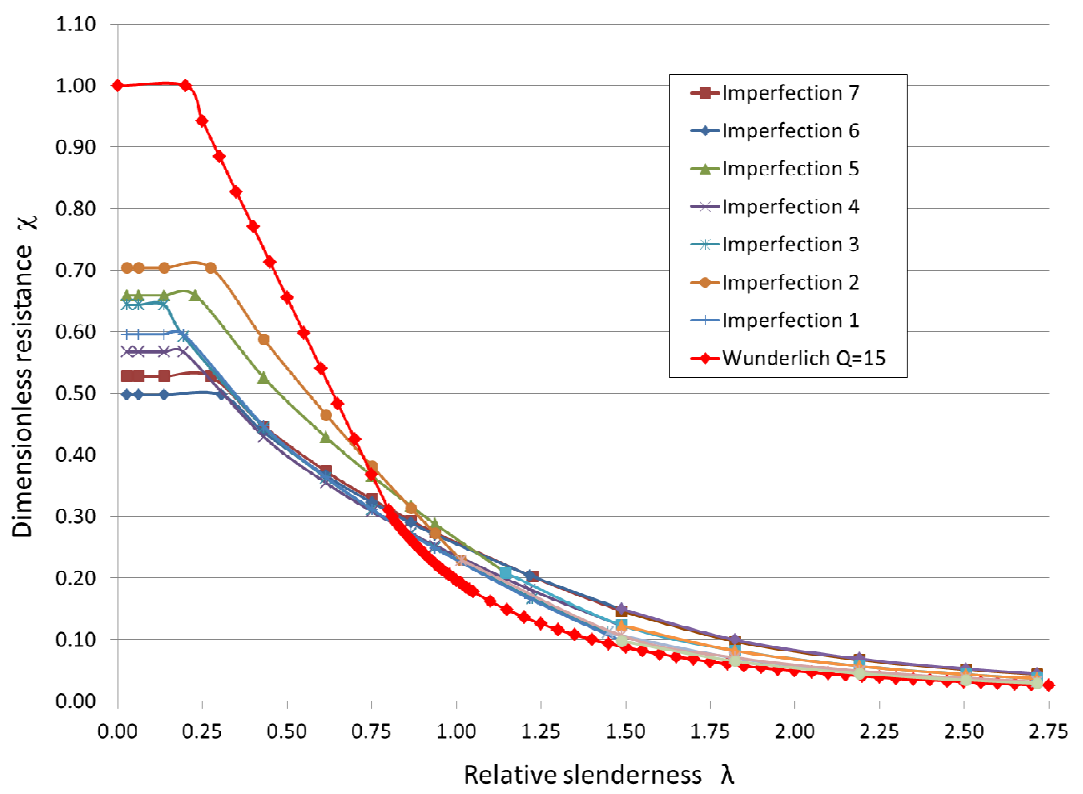

Fig. 8. Standard capacity curves for different imperfection modes of amplitude $1.5 t$

\section{RECAPITULATION}

Elastic, elastic-plastic and plastic capacities of the pressurised caps were considered in the paper. The standard procedure recommended in [5] were adopted. All steps of this procedure were presented in details for most destructive imperfection modes determined in [2] and in reference to the spherical caps of the roadius to thickness ratio $R / t=500$, the semi angle $\varphi=30^{\circ}$ and the clamped basic circle. As a final results the standard capacity curves were obtained and compared with the other proposal presented in [5]. It turned out that the present solution gives smaller estimation of buckling capacity in the plastic and elastic-plastic range and nearly the same estimation for the purely elastic range. These results should arise the curiosity of civil and mechanical engineers and designers of steel spherical shells.

Presented results refer only to the considered class of spherical steel caps subjected to external pressure. The caps of another semiangles and other supporting conditions will be considered in the near future. 
The comparisons of the proposals presented in [5] show especially big discrepancies within the plastic and within the initial part of the elastic-plastic intervals. In the case of the highest imperfection amplitudes the existing proposals are two times higher than the assessment proposed in the present work

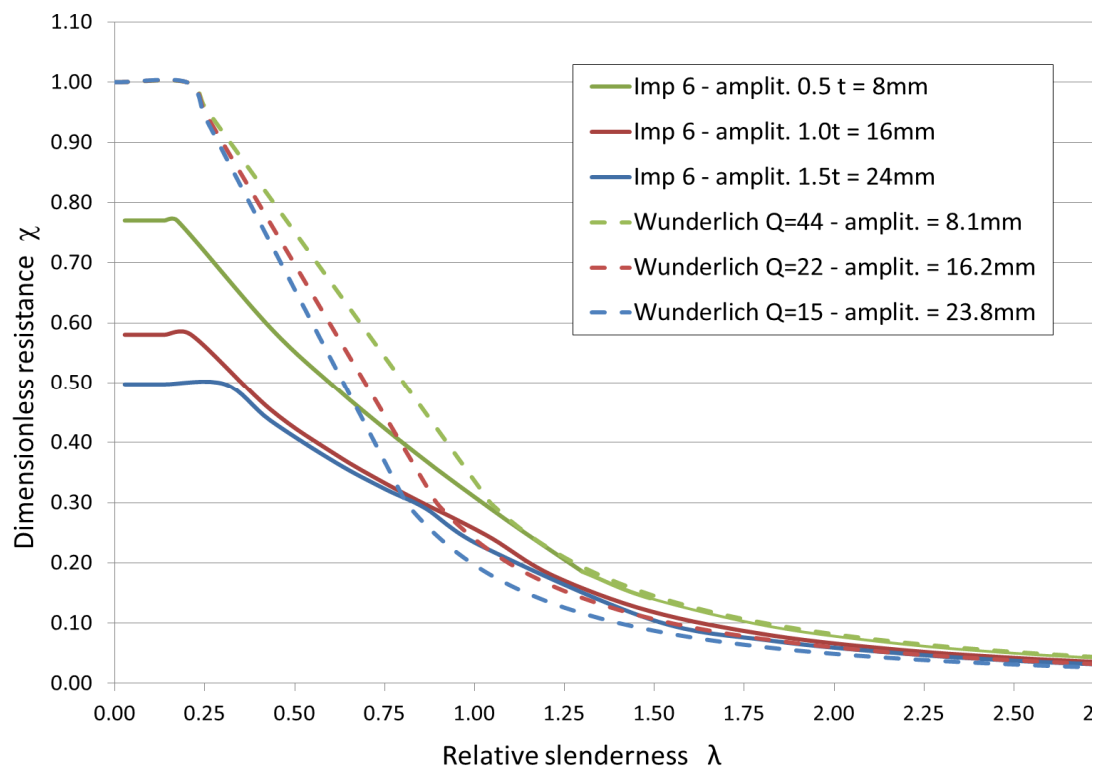

Fig. 9. Final shape of derived capacity curves for worst imperfection modes

\section{REFERENCES}

1. Błażejewski P., Marcinowski J.: (2013), A new approach to the buckling resistance assessment of pressurized spherical shells, SSTA: proceedings of the 10th conference. Gdańsk, Polska, 2013 .- London : Taylor \& Francis Group, 2014, s. 179--182

2. Błażejewski P., Marcinowski J.: (2014), Najbardziej niekorzystne imperfekcje geometryczne stalowych powtok sferycznych, 60 Jubileuszowa Konferencja Naukowa Komitetu Inżynierii Lądowej i Wodnej PAN i Komitetu Nauki PZITB - Krynica 2014.

3. Doerich, C. \& Rotter, J.M.: (2011). Generalised capacity curves for stability and plasticity: Application and limitations. Thin-Walled Structures 49(9): 1132-1140.

4. Rotter, J.M.: (1999), proposal for generalisation of the elastic-plastic buckling interaction rule in Eurocode 3 Part 1.6, CEN TC250/SC3/PT4 \& ECCS TWG8.4 working paper: 8. 
5. Rotter J. M.: (2005), The practical design of shell structures exploiting different methods of analysis. in Shell Structures: Theory and Applications, Eds W. Pietraszkiewicz \& C. Szymczak, Taylor and Francis, London, pp. 71-86.

6. Rotter J. M. and Schmidt H.: (2008), Buckling of Steel Shells. European Design Recommendations 5th Edition. Eds: Published by ECCS.

7. COSMOS/M, Finite Element Analysis System, Version 2.5, Structural Research and Analysis Corporation, Los Angeles, California, 1999.

\section{KRZYWE NOŚNOŚCI WYBOCZENIOWEJ STALOWYCH POWŁOK SFERYCZNYCH OBCIĄŻONYCH CIŚNIENIEM ZEWNĘTRZNYM}

\section{Streszczenie}

Oszacowanie nośności wyboczeniowej stalowej powłoki sferycznej obciążonej ciśnieniem zewnętrznym nie należy do łatwych zadań. Istnieją dwa sposoby, którymi można się posłużyć aby osiągnąć ten cel. Pierwszy z nich to wykonanie zaawansowanych analiz numerycznych, w których uwzględnione zostaną nieliniowości geometryczne i materiałowe oraz najbardziej niekorzystne formy imperfekcji geometrycznych o zadanej amplitudzie. Ten typ analizy nosi nazwę GMNIA, a wykonuje się ją z wykorzystaniem oprogramowania komputerowego bazującego na MES. Druga metoda, względnie prosta, polega na wykorzystaniu gotowych procedur, dzięki którym można określić nośność krytyczną, nośność plastyczną powłoki oraz parametry wyboczeniowe $\alpha, \beta, \eta, \lambda_{0}$, niezbędne do opisania klasycznej krzywej nośności. Wyznaczenie krzywej nośności dla pewnej klasy wycinka powłoki sferycznej jest głównym celem tej pracy. Sposób szacowania nośności krytycznej i plastycznej autorzy przedstawili w pracy [1], zaś określenie najbardziej niekorzystnej imperfekcji geometrycznej dla badanej rodziny powłok sferycznych w pracy [2]. Wyznaczenie parametrów wyboczeniowych opisujących klasyczną krzywą nośności jest znacznie trudniejszym zadaniem, dlatego też autorzy niniejszej pracy wybrali do badań rodzinę powłok stalowych o stosunku promienia do grubości $R / t=500$, połówkowym kącie rozwarcia powłoki $\varphi=30^{\circ} \mathrm{i}$ sposobie podparcia BC2 (podparcia sztywne). Uwzględniając wszystkie, określone w pracy [2], formy imperfekcji geometrycznych o różnych amplitudach (odniesionych do grubości $t$ ) wyznaczono zestawy parametrów wyboczeniowych definiujących krzywą nośności wyboczeniowej. Parametry te określono posługując się procedurami proponowanymi przez Rottera w pracy [3] oraz w pracy [4], w której to przedstawiono sposób wyznaczania dodatkowego współczynnika $k$, służącego do bezpośredniego wyliczenia wykładnika $\eta$. Rezultatem przeprowadzonych analiz są typowe krzywe nośności dla każdej z form imperfekcji o amplitudach wielkości $0,5 t, 1,0 t, 1,5 t$. 
Otrzymane krzywe porównano z obowiązującymi zaleceniami sformułowanymi w [5] (EDR5th) dla różnych klas dokładności wykonania.

Słowa kluczowe: stalowe powłoki sferyczne, nośność wyboczeniowe, krzywe nośności, model numeryczny, MES

Editor received the manuscript: 9.12.2014 